\title{
La subordinación oracional en una gramática española del siglo $X X$ construida según el modelo de la latina y griega
}

\author{
Luis Alberto HERNANDO CUADRADO \\ Universidad Complutense de Madrid \\ lahernando@filol.ucm.es
}

\section{RESUMEN}

En este artículo el autor estudia el tratamiento de la subordinación oracional en la Gramática de la lengua española (1961) de Luis Penagos, uno de los últimos textos representativos de la gramática tradicional en nuestro país. Luis Alberto Hernando Cuadrado en primer lugar analiza el material del profesor del Seminario Menor Pontificio de Comillas, quien, de acuerdo con el contexto socio-cultural de la época, sigue el modelo de dos gramáticas que había escrito antes, una latina y otra griega, para facilitar el aprendizaje de estas, y después reformula la doctrina examinada basándose en los supuestos de la teoría sintáctica actual.

Palabras clave: subordinación oracional, Gramática de la lengua española (1961), Luis Penagos, gramática tradicional, teoría sintáctica actual.

\begin{abstract}
In this article the author studies the treatment of the sentential subordination in the Grammar of the Spanish Language (1961) of Luis Penagos, that is one of last representative texts of the traditional grammar in our country. Luis Alberto Hernando Cuadrado firstly analyzes the material of the teacher of the Pontifical Minor Seminary of Comillas, who, respecting the socio-cultural context of the epoch, continues the pattern of two grammars that he had written before, a Latin one and a Greek one, in order to facilitate their learning, and afterwards he reformulates the examined doctrine according the suppositions of the current syntactic theory.
\end{abstract}

Keywords: sentential subordination, Grammar of the Spanish Language (1961), Luis Penagos, traditional grammar, syntactic current theory.

\section{SUMARIO}

1. Introducción. 2. Las oraciones subordinadas en Luis Penagos. 3. Enfoque de la cuestión desde la perspectiva sintáctica actual. 4. Conclusión. Obras citadas.

\section{Introducción}

El objeto de este artículo es el estudio del tratamiento de la sintaxis oracional en la Gramática de la lengua española (1961) de Luis Penagos, sacerdote jesuita del 
siglo XX (1908-1995) que se dedicó a la enseñanza de las lenguas clásicas y la española en el Seminario Menor Pontificio de Comillas, donde preparó abundante material sobre estos temas para sus alumnos y los estudiantes de otros seminarios y centros de Bachillerato en una época en la que el latín era aún la lengua empleada en la liturgia de la iglesia católica, por lo que había que dedicarle la máxima atención ${ }^{1}$.

L. Penagos, antes de redactar la gramática de nuestra lengua, había compuesto una latina y otra griega, que se reeditaron en numerosas ocasiones, sobre todo la latina, que en 1990 alcanzaba la 29. a edición. En 1959 publicó la Gramática española, a la que en las dos ediciones siguientes, de 1961 - en cuyo texto, como acabamos de apuntar, nos vamos a basar en este trabajo- - y 1963, respectivamente, tituló Gramática de la lengua española. En 1966, aprovechando gran parte del material, publica la Lengua española de primer curso, y en 1967, la Lengua española de segundo curso, cuyos contenidos son en esencia los de la Gramática de la lengua española con algunas modificaciones, especialmente en el terreno de la terminología ${ }^{2}$.

El estudio de la gramática, a juicio de L. Penagos, dado que en ella se barajan una serie de conceptos abstractos, de relaciones verbales mutuas, de reglas y de excepciones, que para un estudiante de diez o doce años se presentan como "un bosque en donde no se atreve a entrar, o de donde no sabe salir"", debe intentarse facilitarlo lo más posible, formulando los preceptos y reglas con claridad, simplicidad y facilidad, con el fin de obtener un efecto pedagógico satisfactorio.

Como los alumnos de centros de Bachillerato y de seminarios en la época en que el jesuita prepara sus textos tienen que cursar la lengua española, más adelante la latina y varios la griega, teniendo en cuenta que la diversidad terminológica y conceptual - a lo que se suma el desconocimiento o escaso conocimiento que se advierte en los alumnos de la gramática española y en especial de la sintaxis-,

${ }^{1}$ El P. Penagos, S. J., cuenta, entre otros, con un ilustre precedente del siglo XIX, R. de Miguel (1816-1878), que, como él, había estudiado Filosofía y Teología, Catedrático de Retórica y Poética en el Instituto San Isidro de Madrid, autor de la Gramática hispanolatina teórico-práctica para el estudio simultáneo de las lenguas latina y castellana comparadas y de la Gramática castellana comparada a la latina.

${ }^{2}$ L. Penagos, además, es autor de "La doctrina del pecado original en el Concilio de Trento", tesis doctoral presentada en la Universidad Pontificia de Comillas en 1934, que publicó en 1945 en Miscelánea Comillas. Revista de Teología y Ciencias Humanas (Vol. 3, N. ${ }^{\circ}$ 4, pp. 127-274), y compilador y editor de una Antología griega (al principio con la colaboración de M. Rodríguez y M. Morán) y un Florilegio latino (inicialmente con la colaboración de G. Ruiz) que tuvieron un enorme impacto en los centros educativos mencionados.

${ }^{3}$ L. Penagos (1961), p. V. 
constituiría una gran dificultad para el aprendizaje de las dos últimas, en las orientaciones metodológicas del Ministerio de Educación Nacional se recomienda la unificación de la terminología en el estudio de los idiomas.

Ante esta situación, el profesor del Seminario Menor Pontificio de Comillas opta por utilizar "el mismo esqueleto, los mismos conceptos, definiciones y divisiones (y en Sintaxis aun las mismas reglas casi literalmente) en las tres Gramáticas, española, latina y griega", los contenidos de la gramática española - algunos de los cuales sin duda inexactos pero útiles-, encuentren menos dificultades en el aprendizaje de las gramáticas latina y griega.

La obra está estructurada en dos partes. En la primera se trata la teoría, agrupada en capítulos y artículos, para que el estudiante pueda percibir la unidad y el orden de los elementos de la gramática. En la segunda se incluye la práctica, consistente en análisis gramaticales, lecturas y ejercicios por escrito. De esta manera, el texto adquiere mayor claridad y el profesor ve facilitada su tarea a la hora de combinar su explicación con la práctica que ha de encomendar al alumno.

La gramática, en el contexto en el que es redactado el texto que constituye el objeto de esta investigación, unos años antes de que fueran introducidas en nuestro país las nuevas tendencias de la lingüística, es definida por L. Penagos como "el conjunto de reglas que enseñan a hablar y escribir correctamente una lengua", dividida en cuatro partes, morfología, que estudia las palabras considerándolas aisladamente; sintaxis, que enseña a unir y ordenar las palabras; fonética, que enseña a pronunciar bien las palabras; y ortografía, que enseña a escribir bien las palabras y usar los signos de la escritura ${ }^{6}$.

\footnotetext{
${ }^{4}$ L. Penagos (1961), p. V.
}

${ }^{5}$ L. Penagos (1961), p. 2. Esta definición de gramática responde a la fórmula tradicional propuesta por Diomedes ("Tota autem grammatica consistit praecipue intellectu poetarum et scriptorum et historiarum expositione et in recte loquendi scribendique ratione" [en $\mathrm{H}$. Keil (ed.) (1981, I), p. 426]), que "se repite con leves variantes en la obra de Prisciano, Ramus o Sánchez de las Brozas y que pasó a convertirse en algo tan perteneciente a la tradición cultural europea que en gran parte de los casos fue admitida sin ninguna discusión ni modificación" (J. J. Gómez Asencio [1981], p. 18), y se mantiene aún en la GRAE ("Gramática es el arte de hablar y escribir correctamente" [1962], p. 7) y en numerosos manuales del siglo XX.

${ }^{6}$ La división cuatripartita de la gramática, propugnada por la Real Academia Española en la $G R A E$ desde la edición de 1796 y llevada a efecto desde la de 1870 (analogía, sintaxis, prosodia y ortografía) y en la mayor parte de las gramáticas de nuestra tradición, se remonta a la división en etimología, sintaxis, prosodia y ortografía, que constituye una deformación de la estructuración grecolatina (analogía, etimología, sintaxis y prosodia) y "arraiga en los más célebres tratadistas del Medioevo, como, por ejemplo, en el famoso Doctrinale de Alexander de Villa Dei” (A. Llorente Maldonado de Guevara [1967], p. 245). 
La oración, definida desde el punto de vista semántico como "la palabra o conjunto de palabras con que expresamos un pensamiento" ", se divide en nueve partes según "el oficio que tienen en la oración"8, cinco variables (sustantivo, adjetivo, artículo, pronombre, verbo) y cuatro invariables (adverbio, preposición, conjunción, interjección), que son estudiadas en la morfología en tres bloques, dedicados, sucesivamente, a los nombres y pronombres, a la flexión verbal y a las voces invariables?.

En la sintaxis, además de analizarse los elementos de la oración, se reformula en dos ocasiones la definición de esta desde la perspectiva lógico-semántica como "la palabra o conjunto de palabras que expresan un juicio, un deseo, un sentimiento, una acción" $" 10$, y se la divide atendiendo a la voz del verbo (activa y pasiva), a la

${ }^{7}$ L. Penagos (1961), p. 1. En el mundo griego Dionisio de Tracia define la oración con el criterio semántico como "una unión de palabras que representan un sentido completo" (en J. Roca Pons [1986], p. 273). El gramático latino Prisciano, siguiendo muy de cerca a Dionisio de Tracia, corrobora que "oratio est ordinatio dictionum congrua sententiam perfectam demonstrans" (en H. Keil [ed.] [1981, II], p. 53). Las definiciones de esta índole son las que más se han repetido a lo largo del tiempo con ligeras variantes. Las encontramos, por ejemplo, en A. Alonso y P. Henríquez Ureña ("la menor unidad del habla con sentido completo" [1971], p. 10), S. Gili Gaya ("unidades de sentido" [2000], p. 20), el Esbozo ("unidades de sentido completo" [1973], p. 349) o el DRAE ("Palabra o conjunto de palabras con que se expresa un sentido gramatical completo" [2001], s. v. oración).

${ }^{8}$ L. Penagos (1961), p. 1.

${ }^{9}$ Este sistema de nueve partes de la oración, en el que, frente al ofrecido por la GRAE desde la edición de 1771 (nombre, artículo, pronombre, verbo, participio, adverbio, preposición, conjunción e interjección) — que constituye la reunión del de ocho de Dionisio de Tracia (en el que la interjección había quedado excluida) y Prisciano (en el que no consta el artículo)-, el sustantivo y el adjetivo son presentados como dos categorías independientes — como se venía haciendo en la GRAE a partir de la edición de 1870 — y el participio —que se mantuvo como parte independiente hasta la edición de 1916 de la GRAE - ha pasado a ser una forma del verbo más siguiendo la tendencia introducida en nuestro país por G. M. de Jovellanos en 1795 bajo la influencia de los gramáticos filósofos franceses. Es el sistema que se registra en la GRAE a partir de la edición de 1917 y en la mayor parte de los textos gramaticales.

${ }^{10}$ L. Penagos (1961), pp. 55 y 72. M. Marín y Peña, que emplea como sinónimos los conceptos de oración y proposición, señala que consiste en "la enunciación de un pensamiento. Normalmente, este pensamiento es un juicio lógico" ([1963], p 89). El logicismo, que, desde Aristóteles (J. M. Gambra Gutiérrez y M. Oriol Salgado [2008]), siempre se ha dejado sentir en los gramáticos, se intensifica en el siglo XVII con el racionalismo francés. De acuerdo con los principios de la Grammaire générale et raisonnée de Port-Royal, se ha solido definir la oración como "la expresión de un pensamiento" o "la expresión de un juicio" (J. Roca Pons [1986], pp. 273-274). E. Sapir la presenta como "la expresión lingüística de una proposición" (en J. Roca Pons [1986], p. 279); S. Gili Gaya, como "la expresión verbal de un 
naturaleza del verbo (atributiva y predicativa), al número de verbos (simple y compuesta) y al modo del verbo (independiente y dependiente).

\section{Las oraciones subordinadas en Luis Penagos}

Las oraciones subordinadas son caracterizadas por L. Penagos, de acuerdo con la denominación predominante de oraciones dependientes que les aplica en el epígrafe de la sección segunda del tratado segundo de la sintaxis oracional — dedicado al estudio de las oraciones según el modo de los verbos- y en las diversas partes del texto, como "las que dependen gramaticalmente de otra oración, llamada principal" , fenómeno que se advierte a primera vista, por ejemplo, en "Vi que Antonio estaba estudiando" o en "Te daré un premio si estudias la lección".

Dentro del grupo de las oraciones subordinadas el autor distingue tres subgrupos, el de las completivas, el de las circunstanciales y el de las relativas, y explica que las primeras "hacen el oficio de complemento o sujeto de la oración principal"" ("Sé que eres bueno" [complemento]; "No importa que no venga" [sujeto]), que las segundas "expresan alguna circunstancia (fin, causa, tiempo...) de la oración principal"13 ("Estudiaba porque se lo mandó su padre"), y que las terceras "están unidas a su oración principal por el pronombre relativo" "14: "Félix, que es bueno, estudia mucho".

juicio" ([2000], p. 21); y la GRAE (1917-1962), como "la expresión del juicio lógico" ([1962], p. 156).

${ }^{11}$ L. Penagos (1961), p. 81.

${ }^{12}$ L. Penagos (1961), p. 81.

${ }^{13}$ L. Penagos (1961), p. 81.

${ }^{14}$ L. Penagos (1961), p. 81. En la Lengua española de segundo curso clasifica las oraciones subordinadas en sustantivas, adverbiales y adjetivas, y comenta que la sustantiva, que "desempeña con relación a la oración principal los oficios que un sustantivo puede desempeñar en la oración simple. Es decir, de sujeto, predicado y complemento (directo, indirecto, circunstancial) y complemento de un sustantivo o adjetivo" ([1967], p. 159), se llama también completiva "porque sin ella la oración principal queda incompleta sintácticamente o sin sentido" ([1967], p. 159); que la adverbial, que "desempeña con relación a la oración principal el oficio de un adverbio" ([1967], p. 159), recibe asimismo la denominación de circunstancial "porque expresa una circunstancia (causa, tiempo, condición, etc.) de la oración principal" ([1967], p. 159); y que a la adjetiva, que “desempeña con relación a la oración principal el oficio de un adjetivo" ([1967], p. 159), suele aplicársele el calificativo de relativa "porque está unida a su oración principal por el pronombre relativo" ([1967], p. 159). M. Marín y Peña, partiendo de la idea de que los elementos de una oración (sujeto, predicado, complementos) pueden presentarse bajo la forma de palabras o de oraciones, explica que las "oraciones que hacen el oficio de elemento de otra oración se llaman subordinadas. La oración que contiene, como elementos de ella, alguna o algunas subordinadas se llama periodo" ([1963], p. 144), y clasifica las oraciones 
En el uso de los modos y tiempos en las oraciones subordinadas, en la consecución de tiempos —en la que se expresan las completivas, y las circunstanciales finales, consecutivas y causales-, consistente en la "correspondencia entre el tiempo del verbo de la oración dependiente con respecto al tiempo del verbo principal" está el verbo principal y, por otro, la relación del verbo dependiente con respecto a él. El verbo principal puede estar en tiempo primario (presente y futuro) o en tiempo secundario (pretérito); y la acción del verbo dependiente puede ser anterior, simultánea o posterior a la del verbo principal.

En la consecución de indicativo, cuando el verbo principal está en tiempo primario, el verbo dependiente está en pretérito ${ }^{16}$ si su acción es anterior ("Digo que vino José"), en presente si es simultánea ("Digo que viene José") o en futuro imperfecto si es posterior ("Digo que vendrá José"), y, cuando el verbo principal está en tiempo secundario, el verbo dependiente está en pretérito pluscuamperfecto si su acción es anterior ("Dije que había venido José"), en pretérito imperfecto si es simultánea ("Dije que venía José") o en potencial simple si es posterior: "Dije que vendría José".

En la consecución de subjuntivo, cuando el verbo principal está en tiempo primario, el verbo dependiente está en pretérito perfecto si su acción es anterior ("Temo que haya venido José") o en presente si es simultánea o posterior ("Deseo que venga José"), y, cuando el verbo principal está en tiempo secundario, el verbo dependiente está en pretérito pluscuamperfecto si su acción es anterior ("Temí que hubiese venido José") o en presente si es simultánea o posterior: "Rogué que viniese José".

En la construcción ordinaria - como se expresan las circunstanciales condicionales, concesivas, comparativas, temporales y locativas-, en la que "uno de los modos y tiempos de los verbos dependientes se rige por el matiz que tenga el verbo en sí, de realidad, posibilidad o irrealidad" ${ }^{\prime 17}$, se tiene en cuenta si la oración es real, potencial o irreal. La real va en indicativo, en pretérito si la acción es pasada ("Luego que llegó, murió"), en presente si es presente ("Si dices esto, yerras"), o en presente de indicativo o de subjuntivo si es futura: "Si viene, lo veré", "Luego que venga, lo veré"; la potencial, en pretérito imperfecto de subjuntivo: "Si hicieses

subordinadas por la función que desempeñan en el período en completivas o sustantivas, "si sirven de sujeto o complemento directo de la principal" ([1963], p. 145); relativas o adjetivas, "si hacen oficio de complemento adnominal o atributo" ([1963], p. 145); y circunstanciales o adverbiales, "si actúan como un complemento circunstancial o un adverbio" ([1963], p. 145).

${ }^{15}$ L. Penagos (1961), p. 81.

${ }^{16}$ Pretérito indefinido, pretérito perfecto o pretérito imperfecto.

${ }^{17}$ L. Penagos (1961), p. 82. 
esto, te daría un premio"; y la irreal, en pretérito pluscuamperfecto de subjuntivo: "Si hubieras estudiado, hubieras aprobado".

Las completivas enunciativas dependen de un verbo de 'entendimiento', 'sentido' o 'lengua' ("Supe que Antonio había muerto"; "He oído que el juez le condenó"; "Dicen que la unión hace la fuerza") y serían independientes enunciativas si no dependiesen de dicho verbo: "Antonio había muerto"; "El juez le condenó"; "La unión hace la fuerza". Las volitivas dependen de un verbo de 'voluntad' ("Quiero que venga Antonio") y serían independientes volitivas si no dependiesen de él: "Que venga Antonio". Las interrogativas (indirectas) están unidas a la oración principal por medio de una palabra interrogativa ("No sé quién ha venido") y serían independientes interrogativas (directas) si no dependiesen de otro verbo: "¿Quién ha venido?".

Las completivas enunciativas llevan el verbo en indicativo precedido de la conjunción que cuando dependen de un verbo de 'entendimiento', 'conocimiento' o 'lengua', como entender, pensar, conocer, ver, oir, decir, manifestar ("Sé que tú harás la casa") ${ }^{18}$, de expresiones verbales constituidas por ser + atributo del tipo de verdadero, falso, cierto, evidente ("Es cierto que los enemigos fueron vencidos"), o de verbos que indican 'suceso', como sucede, resulta, queda: "Resulta que nadie estuvo allí cuando se incendió la casa". El verbo de la completiva va en infinitivo si depende de los auxiliares poder, deber y soler ("Podemos ir a Madrid"), o de empezar, apresurarse, retardar, atreverse y vacilar: "Empezó a leer"; "No se atrevieron a entrar en el castillo"19. Las dependientes de verbos que expresan 'alegría', 'tristeza', 'dolor', 'admiración', así como de alabar, vituperar, acusar, condenar, se construyen indistintamente con su verbo en infinitivo precedido de la preposición de ("Le acusan de robar en las tiendas") o en subjuntivo precedido de la preposición de + la conjunción que: "Me alegro de que haya venido"20.

${ }^{18}$ L. Penagos hace notar que algunas veces las completivas dependientes de estos verbos aparecen en infinitivo ("Afirmó haber visto a Antonio muerto"), e incluso, cuando la principal es negativa, en subjuntivo con la conjunción de subordinación que: "No creo que Antonio estudie" ([1961], p. 84, n. 1).

19 Así es como analiza L. Penagos en la gramática latina las construcciones del tipo de "Possum facere hoc" ([1960], p. 96). Sin embargo, M. Marín y Peña hace notar que estas oraciones de infinitivo solo - o de infinitivo concertadas, como se conocen en la gramática tradicional - constituyen un grupo integrado por auxiliar + infinitivo que "se trata en sintaxis como un solo verbo, porque viene a ser como una forma perifrástica" ([1963], p. $150)$.

${ }^{20}$ A las oraciones subordinadas de este tipo las denomina L. Penagos, siguiendo el modelo de las correspondientes construcciones latinas con quod y ut ("Gaudeo quod es bonus"; "Gaudeo ut sis bonus") ([1960], p. 97), completivas explicativas, debido a que "aclaran o explican una idea incluida en un pronombre (a veces solo implícito) de la principal, o 
Las completivas volitivas van en subjuntivo con consecución de tiempos o en infinitivo. Las dependientes de verbos de 'inclinación', como querer, preferir, desear, permitir, procurar, decidir, llevan el verbo en infinitivo si su sujeto es el mismo que el de la oración principal ("Deseo hacer esto") y en subjuntivo precedido de la conjunción que si es distinto: "Deseo que hagas esto"; las dependientes de los verbos rogar, pedir, exhortar, inducir, mandar, impeler, obligar, hacer, obtener llevan el verbo indistintamente en infinitivo ("Mandé a los soldados hacer esto") o en subjuntivo con la conjunción que: "Mandé que los soldados hiciesen esto"; las dependientes de verbos o expresiones verbales integradas por ser + atributo con el significado de 'necesidad', 'licitud', 'conveniencia', 'utilidad', 'facilidad', 'agrado' también se construyen indistintamente con el verbo en infinitivo ("Me agrada estudiar"; "Es necesario hacer esto") o en subjuntivo con la conjunción que: "Me agrada que estudiéis"; "Es necesario que hagáis esto" ${ }^{21}$. Las dependientes de verbos de "temor' llevan el verbo en infinitivo si su sujeto es el mismo que el de la principal ("Temo llegar a casa") y en subjuntivo con la conjunción que si es distinto: "Temo que los soldados lleguen a mi casa"; las dependientes de los verbos prohibir, impedir, rehusar y evitar llevan el verbo indistintamente en infinitivo ("Te prohíbo ir"; "Rehusaba marcharse") o en subjuntivo con la conjunción que: "Te prohíbo que vayas"; "Evitó que los soldados entrasen en la ciudad".

Las completivas interrogativas van en indicativo con consecución de tiempos. Las interrogativas indirectas simples constan de un solo miembro ("Dime quién ha venido"; "No sé si vendrá tu padre"), y las compuestas se hallan integradas por dos miembros "que se contraponen de alguna manera"22. "No sé si vino o se quedó". Todas las oraciones interrogativas indirectas están unidas con su oración principal "por un pronombre o adverbio interrogativo o por la partícula si"23: "Sé qué haces"; "Dime dónde está César"; "No sé si ha venido Félix".

también indican el motivo o causa de la oración principal: 'Me admiro de esto, de que estudies tanto"” ([1961], p. 84); en la Lengua española las trata como "sustantivas en función de complemento circunstancial" ([1967], p. 162).

${ }^{21}$ El autor explica a continuación el fenómeno de la prolepsis o anticipación del sujeto en estos términos: "Frecuentemente el sujeto de la oración completiva pasa a ser complemento del verbo de la oración principal. Ej.: Rogó a los soldados que marchasen. Rogó que los soldados marchasen" ([1961], p. 85).

${ }^{22}$ L. Penagos (1961), p. 86.

${ }^{23}$ L. Penagos (1961), p. 86. En la Lengua española de segundo curso, como se ha indicado, asigna a las oraciones sustantivas las funciones de sujeto ("Sucedió que nadie estaba alli"), predicado ("La justicia es dar a cada uno lo suyo"), complemento directo (enunciativa ["Sé que estudias mucho"]; volitiva ["Te prohíbo que vayas al monte"]; interrogativa: "Vio quién había venido"; "No sé si vendrá tu padre"), complemento indirecto (las que "indican el fin y 
Las oraciones circunstanciales, atendiendo al hecho de llevar el verbo con consecución de tiempos o en construcción ordinaria, son estudiadas en la sección segunda del tratado segundo en dos capítulos diferentes, el segundo, en el que se explican las oraciones circunstanciales de consecución (finales, consecutivas y causales), y el tercero, en el que se analizan las oraciones circunstanciales de construcción ordinaria (condicionales, concesivas, comparativas, temporales y locativas).

Las finales, que "indican el fin o la intención de la oración principal"24, encabezadas por a, para, a fin de (que), por, llevan el verbo en infinitivo cuando su sujeto es el mismo que el de la oración principal ("Fui a la ciudad $a$ ver a mi amigo") y en subjuntivo o infinitivo cuando los sujetos son distintos: "Te doy la espada para que luches"; "Te doy la espada para luchar"25. Las consecutivas, que "indican el efecto o resultado de la oración principal" ${ }^{\text {"2 }}$ llevan el verbo en indicativo o en subjuntivo con que (en correlación con tal, tanto, tan, así, o precedido de sin, en la principal) ("Era tan bueno que todos le alababan"; "No hizo tanto frío que se helase el rio"; "No perdió la hacienda sin que antes arrastrase a otros a la ruina"), o en infinitivo con hasta ("Hizo frío hasta quedarse el río helado") y — si son negativas - con sin: "No perdió la hacienda sin antes arrastrar a otros a la ruina". Las causales, que "indican la causa por la que se realiza la oración principal"27, cuyos elementos introductores más representativos son porque, ya que, puesto que (o que equivalente a porque), llevan el verbo en indicativo "cuando es porque (es decir, cuando se indica la causa verdadera)" 28 ("Te aman porque eres bueno") y en indicativo o subjuntivo "cuando es no porque"29: "Te aman no porque eres (seas) sabio, sino porque eres bueno".

también se llaman oraciones finales" [(1967), p. 162]: "Te doy la espada para que luches"), complemento circunstancial (las que "indican la causa o motivo de la oración principal, o explican una idea incluida en un pronombre [a veces solo implícito] de la oración principal" [(1967), p. 162]: "Me admiro de esto, de que estudias mucho"; "Te alegraste de que viniese tu madre"), complemento de sustantivo ("Ha llegado la hora de cerrar el edificio") y complemento de adjetivo: "Era muy hábil para escalar los montes".

${ }^{24}$ L. Penagos (1961), p. 88.

${ }^{25}$ L. Penagos, en la Lengua española de segundo curso, primero interpreta las oraciones finales como "sustantivas en función de complemento indirecto" ([1967], p. 162) у a continuación se remite al $\S 157$, donde las estudia entre las adverbiales ([1967], pp. 168169). M. Marín y Peña, en este sentido, observa que "las oraciones finales, que hacen oficio de complemento indirecto, se incluyen por algunos en las substantivas; por los más, entre las adverbiales" ([1963], p. 145).

${ }^{26}$ L. Penagos (1961), p. 88.

${ }^{27}$ L. Penagos (1961), p. 88.

${ }^{28}$ L. Penagos (1961), p. 88.

${ }^{29}$ L. Penagos (1961), p. 88. 
Las condicionales, que "indican la condición mediante la cual se realiza la oración principal" ${ }^{30}$, enlazadas por si, si no, con tal que, en caso de que, con que, según se ha indicado anteriormente, pueden ser reales ("Si dice esto, se equivoca"), potenciales ("Si viniese mi madre mañana, me daría una gran alegría") o irreales ("Si hubieras hecho esto, te hubiera dado un premio"), y en aquellos casos en los que el verbo dependiente va precedido de por si la oración en cuestión es interpretada además como condicional-final: "Compré una espada por si tengo que ir a la guerra" ${ }^{31}$. Las concesivas, que "indican un obstáculo a pesar del cual se realiza la oración principal, o niega la principal admitiendo a la vez alguna circunstancia favorable" ${ }^{\prime 2}$, encabezadas por aunque, por más que, si bien, como las condicionales, suelen ser formuladas como reales ("Aunque no tenía espada, venció"), potenciales (“Aunque no haya sido llamado, vendrá") o irreales: "Aunque no hubiese tenido espada, yo hubiera vencido".

Las comparativas son "las oraciones con las que se compara la oración principal" 33 . Las de igualdad, semejanza y desemejanza llevan como marcas distintivas la conjunción como ("No habla como escribe"), los correlativos tal... cual, tanto... cuanto ("Las pinturas eran tales cuales pedía la grandeza del palacio") o las locuciones igual que, del mismo modo que, de semejante manera que: "Trataba a los ricos del mismo modo que a los pobres"; y las de superioridad, inferioridad o preferencia se construyen con "la partícula que" ${ }^{34}$ precedida de los adverbios más ("Lee más fácilmente que escribe"), menos ("Tal vez haga menos que lo que pueda"), antes ("Antes morirá que huir del enemigo"), o de un comparativo: "Antonio habla peor que escribe". Las comparativo-condicionales, introducidas por como si, y las comparativo-consecutivas —en cuya principal hay un adjetivo o adverbio cuantificado-, encabezadas por para que, van en subjuntivo: "Me ama como si fuese su padre"; "Era muy pequeño para que fuese visto"; "El monte es demasiado alto para que podamos llegar a su cima"35.

${ }^{30}$ L. Penagos (1961), p. 89.

${ }^{31}$ En opinión del autor, frente a las estructuras de los ejemplos propuestos, que contienen "una sola condición" ([1961], p. 89, n. 1), por lo que las oraciones condicionales correspondientes son simples, en otras construcciones del tipo de "Si estudias te alabaré, pero si enredas te reprenderé", que contienen "dos condiciones que se contraponen de alguna manera" ([1961], p. 89, n. 1), nos hallamos ante oraciones condicionales dobles.

${ }^{32}$ L. Penagos (1961), p. 90.

${ }^{33}$ L. Penagos (1961), p. 90.

${ }^{34}$ L. Penagos (1961), p. 91.

${ }^{35}$ Como se ha podido comprobar por algunos de los ejemplos propuestos, las oraciones modales, mencionadas por el autor en la clasificación general de las circunstanciales ("Las oraciones circunstanciales se dividen en finales, consecutivas, causales, condicionales, 
Las temporales, que "indican el tiempo en que se realiza su oración principal"36, introducidas por cuando, después que, luego que, tan pronto como, siempre que, desde que, mientras que, hasta que, antes que, la mayor parte de las veces se formulan como reales, tanto en el pasado ("Cuando vino, le vi") como en el presente ("Desde que estoy en casa, nadie ha llamado a la puerta") o en el futuro ("Luego que venga, le veré") ${ }^{37}$, produciéndose el fenómeno de la repetición de actos en aquellos casos en los que, "siempre que se realiza la acción del verbo dependiente, se realiza también la acción del verbo principal" "38, en cuyo caso "las partículas temporales equivalen a siempre que"39: "Luego que caía, se levantaba". Las locativas, que "indican dónde se realiza la oración principal" 40 , introducidas por (preposición +) donde, normalmente son reales como las anteriores ("Estuve durmiendo donde habia muchas hormigas"), dándose la circunstancia de que, cuando son de futuro, el verbo está en presente de subjuntivo: "Iré donde tú vayas" $"$.

Las oraciones relativas, llamadas así porque "están unidas a su principal por el relativo" ${ }^{, 42}$, pueden ser adjetivas, circunstanciales y completivas. Las adjetivas, que "se refieren a un nombre de la oración principal, al que determinan o modifican a la manera del adjetivo"43, y por lo común van en indicativo, se subdividen en determinativas, las que determinan a un antecedente especificándolo ("Los árboles que cortamos tenían mucha fruta"), y explicativas, las que expresan algún detalle o cualidad del antecedente: "Vi a Antonio, el cual traía una pelota en la mano". Las circunstanciales, que "equivalen a alguna oración circunstancial" 44 y suelen ir en su mismo modo y tiempo, se clasifican en finales ("Envié exploradores que viesen los campamentos enemigos"), consecutivas ("Tendrás una espada con la que puedas matar"), causales ("César, que era de ánimo generoso, se ganó a todos"),

concesivas, comparativas, temporales, locativas y modales" [(1961), p. 87]) pero no tratadas después en artículo aparte, se encuentran fusionadas con las comparativas.

${ }^{36}$ L. Penagos (1961), p. 91.

${ }^{37}$ Las reales de futuro, como se ve, llevan el verbo en subjuntivo, modo en el que aparecen también las encabezadas por antes que: "Huyó antes que viniese César".

${ }^{38}$ L. Penagos (1961), p. 91.

${ }^{39}$ L. Penagos (1961), p. 91.

${ }^{40}$ L. Penagos (1961), p. 92.

${ }^{41}$ En la Lengua española de segundo curso las oraciones modales cuentan con un parágrafo aparte, en el que son caracterizadas como "aquellas oraciones dependientes que indican el modo como se realiza la oración principal" ([1967], p. 177): "Llegó llorando"; "Sufría sin quejarse".

${ }_{42}^{4}$ L. Penagos (1961), p. 93.

${ }^{43}$ L. Penagos (1961), p. 93.

${ }^{44}$ L. Penagos (1961), p. 93. 
condicionales ("El soldado que retrocede es un cobarde"), concesivas ("Yo, que no sabía francés, entendía a los franceses"), comparativas ("Era tal el paisaje cual nunca lo habia visto") y locativas: "Estuve en la casa en que tú viviste". Las completivas desempeñan con respecto al verbo de la oración principal las funciones de sujeto ("Sucedió lo que nadie esperaba"), predicado ("Yo soy el que se va") o complemento directo: "Te diré lo que ha sucedido"45.

El infinitivo, gerundio y participio son los "modos impersonales del verbo"46. El infinitivo "desempeña el oficio de una oración o equivale a una oración completiva o circunstancial"47, presentando el completivo las variantes de completivo enunciativo ("El decir esto es un disparate"; "Le acusan de robar en las tiendas") y completivo volitivo ("Temo llegar a casa"), y el circunstancial, las de circunstancial final ("Fui a la ciudad para ver a mi madre"), consecutivo ("Hizo frío hasta helarse el vino"), causal ("Está en la cárcel por matar a su hermano"), condicional ("De venir tu hermano, no hubiera marchado yo"), concesivo ("Con ser el jefe, nadie le hace caso") y temporal: "Al llegar el general, todos se pusieron de pie" ${ }^{, 4}$. El gerundio "desempeña el oficio de una oración y equivale a una oración

${ }^{45}$ En las combinaciones de $e l$ y paradigma + relativo, a juicio del autor, las formas $e l, l a, l o$, los, las "pueden conservar el primitivo valor de pronombre demostrativo aquel, aquella, aquello, etc. (ille, illa, illud) y constituir el antecedente del relativo" ([1961], p. 93, n. 1) ("Yo soy el que [= aquel que] venció"; "No pidas lo que [= aquello que] no has de conseguir"), y otras veces "la palabra $e l, l a$ es artículo" ([1961], p. 93, n. 1): "Esperaba a César, el cual llegó tarde".

${ }^{46}$ L. Penagos (1961), p. 94. A este respecto, hemos de tener en cuenta que el P. Penagos distingue ocho modos en el verbo latino (indicativo, imperativo, subjuntivo, infinitivo, participio, supino, gerundio, gerundivo) ([1960], p. 24) y siete en el verbo español (indicativo, subjuntivo, potencial [introducido en la GRAE desde la edición de 1917], imperativo, infinitivo, gerundio y participio) ([1961], pp. 28-29). M. Marín y Peña, que reconoce en el verbo latino "tres modos personales (indicativo, imperativo, subjuntivo)" ([1963], p. 39) y "varias formas nominales" ([1963], p. 39), afirma que estas "son substantivos y adjetivos verbales, en los que el carácter de verbo predomina sobre el de nombre" ([1963], p. 176), debido a que "pueden ser modificados por adverbios" ([1963], p. 176) ("recte vivere" = "vivir rectamente") o "ir acompañados por los mismos complementos que el verbo personal" ([1963], p. 176): "causa videndi Romam" = "la causa de ver Roma". Tales formas tradicionalmente solían estar incluidas en el modo infinitivo, como en la GRAE (1917-1962), donde se indica que los modos son cinco (indicativo, imperativo, potencial, subjuntivo, infinitivo). Actualmente, en las gramáticas se habla de tres modos (indicativo, subjuntivo e imperativo) al privarse de dicho carácter a las formas no personales del verbo (infinitivo, gerundio, participio) y pasar el potencial a formar parte del indicativo.

${ }^{47}$ L. Penagos (1961), p. 94.

${ }^{48}$ En la Lengua española de segundo curso, en lugar de hablarse del infinitivo enunciativo y del infinitivo circunstancial, se especifica que este modo impersonal del verbo forma 
circunstancial o adjetiva" ${ }^{\text {, }}$, actuando, por tanto, como una oración circunstancial causal ("Siendo tan bueno Félix, todos le amarán"), condicional ("Favoreciéndonos las circunstancias, venceremos"), concesiva ("Aun habiendo venido de prisa, no pudo ver a su padre") o temporal ("Reinando Isabel y Fernando, los españoles descubrieron América"), o bien como una oración adjetiva ("He visto un soldado jugando") o modal: "Las aguas corrían formando arroyo" ${ }^{50}$. El participio pasivo, de manera similar al gerundio, "desempeña el oficio de una oración y equivale a una oración circunstancial o adjetiva", podía andar"), condicional ("Ayudados por César, hubiéramos vencido"), concesivo ("Félix, aun ayudado por su hermano César, no pudo arrastrar la pierna") o temporal ("Derribado el muro, los soldados entraron en la ciudad"), o bien adjetiva ("Los traidores, colgados de los árboles, sirvieron de escarmiento") o modal: "Juan murió sentado en una silla"

oraciones dependientes que desempeñan las funciones de sujeto ("Obrar con reflexión es conveniente"), predicado ("Justicia es dar a cada uno lo suyo"), complemento directo ("Deseo estudiar"), complemento indirecto "(como oración final)" ("Fui a casa para ver a mi madre") y complemento circunstancial (desglosado en las mismas clases que en la Gramática de la lengua española). Previamente, se trata el infinitivo que forma oraciones independientes, histórico (equivalente, "como en latín, al pretérito imperfecto de indicativo" [(1967), p. 188]) ("No me hablaba de otras cosas y todos a condenarme e ir al monasterio" [Santa Teresa]), imperativo (“¡A callar todos!”) o exclamativo: “iIrme yo con él!”. El punto de partida lo constituye el infinitivo usado como nombre, del que se afirma que "hace los mismos oficios sintácticos que el nombre" ([1967], p. 187) ("El querer [sujeto] es poder [predicado]"; "Es tiempo de callar" [complemento determinativo]), que "puede llevar complementos determinativos" ([1967], p. 187) ("El sonreir de los niños es agradable") y que "como nombre se le considera de género masculino" ([1967], p. 187).

${ }^{49}$ L. Penagos (1961), p. 95.

${ }^{50}$ El gerundio se usa en forma concertada, "cuando su sujeto es sujeto o complemento directo de la oración principal ("Luchando los soldados vencieron"), o en forma absoluta, "cuando su sujeto no es ni sujeto ni complemento directo de la oración principal": "Luchando los soldados, el general huyó". Por otro lado, los gerundios circunstanciales simples y compuestos "se pueden cambiar formando una oración con la partícula como y poniendo el verbo en subjuntivo" ([1961], p. 96): "Siendo estudioso, sacó buenas notas" = "Como fuese estudioso, sacó buenas notas"; "Habiendo vencido a los enemigos, entró triunfante en la ciudad" = "Como hubiese vencido a los enemigos, entró triunfante en la ciudad".

${ }^{51}$ L. Penagos (1961), p. 96.

${ }^{52}$ El participio está usado en forma concertada "cuando su sujeto es sujeto o complemento directo de su oración principal" ([1961], p. 96) ("Los soldados vencidos huyeron"), y en forma absoluta, "cuando su sujeto ni es sujeto ni complemento directo de su oración principal" ([1961], p. 96): “Asesinado el general, huyeron los soldados". Los participios pasivos circunstanciales, igual que los gerundios del mismo tipo, "se pueden cambiar 
Las oraciones de estilo indirecto son "aquellas que refieren los dichos y pensamientos de otro, no de la misma manera que él las expresó, sino dependiendo de un verbo de decir" ${ }^{53}$. Como consecuencia de ello se producen cambios en los tiempos verbales, y en los pronombres y adverbios. En este sentido, si el verbo de decir está en tiempo secundario, los verbos que pasan a estilo indirecto siguen las pautas de la consecución de tiempos. Del mismo modo, los pronombres personales y las personas de los tiempos pasan a tercera persona. $\mathrm{Y}$ los restantes pronombres y los adverbios son sustituidos por sus correspondientes que signifiquen lejanía en el tiempo y el espacio (este y ese, por ejemplo, pasan a aquel; ahora, a entonces; hoy, a aquel día; aquí, a allí, etc.). La secuencia

El senador Cayo dijo al Senado: Quiero estar sordo para no oír estos decretos que han de ser la deshonra para los romanos. Yo lamento este cambio de pareceres en vosotros, senadores. ¿No es cierto que os jactéis de no ceder ante Alejandro? Entregad, si queréis, a estos enemigos las ciudades que vuestros padres conquistaron con su sangre ${ }^{54}$

es un ejemplo de estilo directo, que, al ser formulada en estilo indirecto, queda como sigue:

El senador Cayo dijo al Senado que quería estar sordo para no oír aquellos decretos que habian de ser deshonra para los romanos. Que lamentaba aquel cambio de pareceres en ellos, los senadores. Si no era cierto que ellos se habian jactado de no ceder ni ante Alejandro. Que entregasen, si querian, a aquellos enemigos las ciudades que sus padres habian conquistado con sangre ${ }^{55}$.

formando otra oración con la partícula como y poniendo el verbo en subjuntivo" ([1961], p. 97): "Vencidos los enemigos, entró triunfante" = "Como hubiesen sido vencidos los enemigos, entró triunfante". Como hace notar el autor, "el participio pasivo tiene el mismo uso que el gerundio compuesto pasivo" ([1961], p. 97): "El general, habiendo sido herido..." = "El general, herido..."; "Habiendo sido ayudados por César..." = "Ayudados por César..."; "Félix, aun habiendo sido ayudado..." = "Félix, aun ayudado...".

${ }^{53}$ L. Penagos (1961), p. 98.

${ }^{54}$ L. Penagos (1961), p. 98.

${ }^{55}$ L. Penagos (1961), p. 98. Para tener una visión más amplia sobre el particular, puede consultarse el trabajo de Luis Alberto Hernando Cuadrado "Sobre los estilos del discurso referido" (en J. Romera Castillo et al. [eds.], Semiótica(s). Homenaje a Greimas, Madrid, Visor, 1994, pp. 251-257). 


\section{Enfoque de la cuestión desde la perspectiva sintáctica actual}

En la actualidad, la gramática, concebida como "la parte de la lingüística que estudia la estructura de las palabras, las formas en que estas se enlazan y los significados a los que tales combinaciones dan lugar" ${ }^{156}$, en lugar de estar organizada en torno a las cuatro partes reconocidas tradicionalmente, se estructura en tres disciplinas, la morfología, que "se ocupa de la estructura de las palabras, su constitución interna y sus variaciones" $" 57$ y la sintaxis, a la que corresponde "el análisis de la forma en que se combinan y se disponen linealmente, así como el de los grupos que forman" ${ }^{258}$, que constituyen la gramática en sentido estricto, a las que se añade la tercera, formada por la fonética, cuyo cometido es "el análisis de los sonidos del habla",59 y fonología, "el de su organización lingüística" ${ }^{60}$, que se considera parte de la gramática en sentido amplio.

Asimismo, se parte de la distinción entre enunciado, unidad lingüística de comunicación, y oración, el esquema sintagmático verbal u oracional del enunciado, caracterizado por contener un verbo en forma personal en su estructura, frente al sustantivo, adjetivo y adverbial, que en última instancia suelen ser reductibles a él tras ser catalizados los elementos del sistema elididos, y se reconocen tres tipos de oraciones, simple, compuesta y compleja, que se diferencian en que la simple contiene una sola relación predicativa ("Matilde estudia Farmacia"), la compuesta está formada por varias oraciones coordinadas ("Compone canciones $y$ toca el piano"), y en la compleja alguna oración está transpuesta a la categoría del sustantivo ("Me alegro de que te encuentres bien"), del adverbio ("Dejé los platos donde estaban") o del adjetivo ("Los árboles que cortamos tenían mucha fruta") y aparece subordinada al verbo, en los dos primeros casos, o a alguno de los núcleos nominales, en el tercero, de la denominada en la tradición gramatical oración principal. Así, pues, la subordinación oracional constituye el objeto de estudio de la oración compleja.

Las oraciones completivas de que habla L. Penagos en la Gramática de la lengua española hoy son tratadas bajo el epígrafe de oraciones sustantivas — denominación que, como hemos tenido ocasión de comprobar, él mismo les daría también en la Lengua española de segundo curso- debido a que se hallan constituidas por una primitiva oración transpuesta a la categoría del sustantivo por medio de un

${ }^{56}$ Real Academia Española y Asociación de Academias de la Lengua Española (2009), p. 3. En la Gramática descriptiva I. Bosque y V. Demonte apuntan que la gramática es "la disciplina que estudia sistemáticamente las clases de palabras, las combinaciones posibles entre ellas y las relaciones entre esas expresiones y los significados que puedan atribuírseles" ([1999], p. XIX).

${ }^{57}$ Real Academia Española y Asociación de Academias de la Lengua Española (2009), p. 3.

${ }^{58}$ Real Academia Española y Asociación de Academias de la Lengua Española (2009), p. 3.

${ }^{59}$ Real Academia Española y Asociación de Academias de la Lengua Española (2009), p. 3.

${ }^{60}$ Real Academia Española y Asociación de Academias de la Lengua Española (2009), p. 3. 
transpositor. Las transpuestas por la conjunción que son susceptibles de desempeñar las funciones de sujeto ("Me agrada que estudiéis"), complemento directo ("Los guardias no impidieron que la madre hablase al prisionero") ", suplemento ("Te alegraste de que viniese"), complemento circunstancial ("Te doy la espada para que luches") y atributo: "El problema es que este año ha llovido poco". Cuando se trata de una interrogativa directa total, el transpositor es la partícula si, pudiendo actuar el segmento en conjunto como sujeto ("No se sabe si vendrá mañana"), complemento directo ("Le preguntó si se encontraba animado"), suplemento ("No se acuerda de si apagó las luces") o complemento circunstancial: "Abrígate bien por si hace frio". Una oración interrogativa directa parcial, con la concurrencia de los relativos tónicos, es susceptible de ser transpuesta a la categoría del sustantivo con la consiguiente pérdida de la curva melódica interrogativa y desempeñar las funciones de sujeto ("Se ignora quién lo sustituirá"), complemento directo ("Dime dónde está César") o, con menor frecuencia, de suplemento: "Se admiraba de cómo habían salido de alli",62.

En el tratamiento de las oraciones circunstanciales L. Penagos estudia por separado en la Gramática de la lengua española, como se ha visto, las de consecución y las de construcción ordinaria, mientras que en la Lengua española de segundo curso, donde emplea el término adverbiales, las estudia todas juntas en un solo capítulo. En la actualidad está claro que debemos aplicar la denominación de subordinación circunstancial para referirnos en general a todas las oraciones transpuestas que desempeñan la función de complemento circunstancial (locativas, temporales, modales, causales, finales, condicionales, concesivas) y reservar la de subordinación adverbial solo para las tres primeras cuando se construyen sin antecedente expreso, ya que, como advierte E. Alarcos Llorach, "pueden funcionalmente ser sustituidas por un adverbio"63: "Yo lo hice cuando me avisaste" (= "Yo lo hice entonces"); "Puso el cuadro donde había más luz" (= "Puso el cuadro alli"); "Tratadlo como se merece" (= "Tratadlo asi") ${ }^{64}$.

${ }^{61}$ Las subordinadas sustantivas en estilo directo ("El médico le dijo: tómese tres cápsulas diarias") desempeñan dentro de la estructura oracional la función de complemento directo al ser conmutables por la forma pronominal átona neutra lo como sus equivalentes en estilo indirecto ("El médico le dijo que se tomara tres cápsulas diarias"): "El médico se lo dijo".

${ }_{62}$ En tales casos, entre los relativos tónicos y los átonos pueden fijarse las siguientes equivalencias en cuanto a su composición interna: qué $=$ artículo $+q u e ;$ cuál $=$ artículo $+q u e$; cuánto $=$ artículo + que; quién $=$ artículo + noción de 'persona' + que; dónde $=$ artículo + noción de 'lugar' + preposición + que; cuándo $=$ artículo + noción de 'tiempo' + preposición + que; cómo = artículo + noción de 'modo' + preposición + que.

${ }_{63}^{63}$ E. Alarcos Llorach (1994), p. 357.

${ }^{64}$ En dichas construcciones los adverbios relativos donde, cuando y como, sin antecedente expreso, al acumular, además del valor de relativo general y de las nociones de 'lugar', 'tiempo' y 'modo', respectivamente, los valores de artículo y preposición, transponen la primitiva 
En las oraciones causales, en las que suelen distinguirse dos tipos de relación semántica según que la oración transpuesta se refiera a la causa real de la experiencia evocada por el verbo principal ("Está enfermo porque ha llevado mala vida") o explique meramente el motivo por el cual se expresa el núcleo del enunciado ("Está enfermo porque tiene mal aspecto"), el transpositor más representativo y frecuente es porque, integrado por la conjunción que, que transpone la primitiva oración a la categoría del sustantivo, y la preposición por, que actúa como índice de la función de complemento circunstancial que contrae el segmento categorialmente sustantivo con respecto al verbo de la oración principal. En construcciones como "Ya que no quieres el libro, me quedaré con él” y "En vista de que no interviene nadie más, se levanta la sesión", cuya oración causal se encuentra encabezada por una locución conjuntiva, el segmento que desempeña la función de adyacente oracional en conjunto se desglosa en otros dos que cumplen, respectivamente, las funciones suboracionales de núcleo nominal y adyacente nominal; en la primera, el núcleo nominal es el adverbio ya, y la primitiva oración no quieres el libro, transpuesta a la categoría del adjetivo mediante el que relativo, funciona como adyacente nominal suyo, y en la segunda, el núcleo nominal es el sustantivo vista, precedido de la preposición en, que actúa como índice de la función de adyacente oracional, y la primitiva oración no interviene nadie más, transpuesta a la categoría del sustantivo con la conjunción que y seguidamente a la del adjetivo por la preposición de, funciona como adyacente nominal suyo.

Las oraciones finales, que "se refieren al propósito o a la intención con que se produce la noción designada por el núcleo verbal" ${ }^{165}$, suelen ir encabezadas por la combinación para que, como en "Leía para que le viniera el sueño", donde la conjunción de subordinación que transpone la primitiva oración le viniera el sueño a la categoría del sustantivo y la preposición para actúa como índice de la función de complemento circunstancial. En construcciones del tipo de "Te he enviado el contrato de compraventa a fin de que lo analices detenidamente", cuya oración final se encuentra encabezada por una locución conjuntiva, el segmento que desempeña la función oracional de complemento circunstancial en conjunto se desglosa en otros dos que cumplen, respectivamente, las funciones suboracionales de núcleo nominal y adyacente nominal; el núcleo nominal es el sustantivo fin, precedido de la preposición $a$, que actúa como índice de la función de complemento circunstancial, y la primitiva oración lo analices detenidamente, transpuesta a la categoría del sustantivo con la

oración, en cuyo interior desempeñan la función de complemento circunstancial, a la categoría del adverbio, y el segmento resultante cumple idéntica función con respecto al verbo de la oración principal: "Donde (=En el [lugar (en)] que) hay patrón, no manda marinero"; "Cuando $(=$ En el [momento (en)] que) el dinero habla, todos callan"; "Lo hará como (= de la [manera] que) tú le digas".

${ }^{65}$ E. Alarcos Llorach (1994), p. 369. 
conjunción que y seguidamente a la del adjetivo por la preposición de, funciona como adyacente nominal suyo.

Las oraciones condicionales, transpuestas con la conjunción si ("Si no duermo, tendré que encender la luz") "funcionan como adyacente o modificador de la oración 'principal' conjunta" ${ }^{66}$. En las construcciones con prótasis y apódosis predomina el sentido condicional, pero su referencia no siempre consiste en formular una condición para el cumplimiento de lo indicado en la otra oración, ya que con frecuencia, en casos como "Si ayer llovía, hoy hace sol", señala únicamente el contraste entre dos realidades compensadas. En construcciones como "Podríamos adoptar esta medida siempre que todos estuviéramos de acuerdo" y "Te dejo mis apuntes a condición de que me los devuelvas el lunes", cuya oración condicional se encuentra encabezada por una locución conjuntiva, el segmento que desempeña la función de complemento circunstancial en conjunto se desglosa en otros dos que cumplen, respectivamente, las funciones suboracionales de núcleo nominal y adyacente nominal; en la primera, el núcleo nominal es el adverbio siempre, y la primitiva oración que todos estuviéramos de acuerdo, transpuesta a la categoría del adjetivo mediante el que relativo, funciona como adyacente nominal suyo, y en la segunda, el núcleo nominal es el sustantivo condición, precedido de la preposición $a$, que actúa como índice funcional, y la primitiva oración me los devuelvas el lunes, transpuesta a la categoría del sustantivo con la conjunción que y seguidamente a la del adjetivo por la preposición de, funciona como adyacente nominal suyo.

El tipo más representativo de las oraciones concesivas, que expresan una objeción o dificultad para el cumplimiento de lo que se dice en la oración principal pero sin impedir su realización, es el introducido por aunque, amalgama fonética y gráfica del adverbio aún y el relativo que ("Aunque se vista de seda, la mona mona se queda"), cuya función "es la del adyacente que hemos llamado modificador oracional, el cual es susceptible de aparecer en cualquier puesto de la secuencia aislado entre pausas"67. Así, en el ejemplo anterior, la forma aunque se desglosa funcionalmente en el adverbio aún, que constituye el núcleo del grupo sintagmático nominal, y el relativo que, que transpone la originaria oración se vista de seda a la categoría del adjetivo capacitándolo para funcionar como adyacente nominal; y todo el segmento en conjunto desempeña la función unitaria de adyacente oracional. También se emplean otros elementos transpositores, especialmente la locución conjuntiva a pesar de que, como en el enunciado "A pesar de que hay poca luz, puedo seguir leyendo", donde el segmento que desempeña la función de adyacente oracional en conjunto se desglosa en otros dos que cumplen, respectivamente, las funciones suboracionales de núcleo nominal y adyacente nominal; el núcleo nominal es el infinitivo sustantivado pesar,

${ }^{66}$ E. Alarcos Llorach (1994), p. 376.
${ }^{67}$ E. Alarcos Llorach (1994), p. 373. 
precedido de la preposición $a$, que actúa como índice funcional, y la primitiva oración hay poca luz, transpuesta a la categoría del sustantivo con la conjunción que y a continuación a la del adjetivo por la preposición de, funciona como adyacente nominal suyo.

L. Penagos, según se ha podido observar, caracteriza las oraciones relativas como las que se unen a la principal por medio del relativo y las clasifica en adjetivas, circunstanciales —en la Lengua española de segundo curso utiliza el término adverbiales, como se ha indicado anteriormente - y completivas, atendiendo a sus posibilidades funciones, en los casos primero y tercero, y al sentido, en el segundo. Para ser exactos, en nuestros días podemos afirmar que, a pesar de que los relativos sean los únicos elementos lingüísticos capaces de convertir en transposición simple una primitiva oración a la categoría del adjetivo ("El traje que lleva puesto se lo han hecho a medida"), el paralelismo entre las denominadas oraciones adjetivas y oraciones de relativo no es total, dado que, por un lado, hay relativos que en determinados contextos, en virtud de los valores gramaticales que contienen, transponen ulteriormente la oración adjetiva a la categoría del sustantivo ("Quien a nadie debe a nadie teme") o a la del adverbio ("Se sacó el carné de conducir cuando estuvo en Cuenca"), y, por otro, la adjetivación de oraciones con frecuencia se logra mediante otras transposiciones encadenadas llevadas a cabo por elementos distintos a los relativos: "La causa de que no hayan llegado a tiempo ha sido la lluvia"68. Las oraciones complejas comparativas y consecutivas, que incluyen una oración degradada, se insertan dentro de un grupo nominal unitario y, como las de relativo, no cumplen ninguna de las funciones adyacentes del núcleo verbal; por tanto, estos dos tipos de oraciones "no son otra cosa que oraciones degradadas, análogas a las relativas, con la diferencia de que su llamado antecedente es un cuantificador o una unidad cuantificada" "69: "Se miente más que se engaña"; "Es meta tan alejada que nadie puede alcanzarla".

El infinitivo, gerundio y participio, en la Gramática de la lengua española de L. Penagos, como se ha podido observar, son presentados como modos impersonales del verbo que algunas veces se utilizan como nombres (sustantivos o adjetivos), haciéndose hincapié en el funcionamiento del infinitivo en las oraciones completivas (enunciativa, volitiva) y circunstanciales (final, consecutiva, causal, condicional, concesiva, temporal) - en la Lengua española de segundo curso se distingue si está empleado como nombre (sujeto, predicado, complemento determinativo), o como

${ }^{68}$ Los relativos, cuyo contenido significativo se reduce a hacer referencia al del antecedente, manifestado previamente en el enunciado oracional $\mathrm{u}$ omitido, en cuanto elementos bifuncionales que son, ejercen la mencionada misión transpositora y, además, desempeñan una función determinada en la oración que transponen, característica que los diferencia del resto de los medios de transposición.

${ }^{69}$ E. Alarcos Llorach (1994), p. 341. 
verbo (en oraciones independientes [histórico, imperativo, exclamativo] o en oraciones dependientes [sujeto, predicado, complemento directo, complemento indirecto, complemento circunstancial (consecutivo, causal, condicional, concesivo, temporal)]) - , en el del gerundio en las oraciones circunstanciales (causal, condicional, concesiva, temporal) y adjetivas (adjetiva, modal), y en el del participio en las oraciones circunstanciales (causal, condicional, concesiva, temporal) y adjetivas (adjetiva, modal). Desde nuestra perspectiva, estas formas no personales del verbo no son modos, sino unidades derivadas del lexema verbal que desempeñan las funciones propias de los sustantivos, de los adverbios y de los adjetivos, respectivamente. Aunque funcionalmente "ni son verbos ni constituyen oración" $" 70$, actúan como núcleo dentro del grupo complejo unitario y pueden llevar adyacentes análogos a los que recibe el verbo en la oración. Estas unidades derivadas verbales "están constituidas por el signo léxico y un derivativo que les confiere otras posibilidades funcionales y la capacidad de aceptar morfemas de tipo nominal" ${ }^{171}$.

Las funciones desempeñadas por el infinitivo, "derivado verbal cuyo significante agrega al del signo léxico del verbo un sufijo que adopta una de las formas ar, er, $i r$ ", artículo (el comer) y desempeñar en la oración las funciones de sujeto ("Me molesta oir siempre lo mismo"), complemento directo ("Espero leer pronto tu libro"), suplemento ("Se esfuerza por complacer a todo el mundo"), complemento indirecto ("No da ninguna importancia a tener riquezas"), complemento circunstancial ("Aprobó por saberse bien la teoría"), atributo ("Querer es poder"), adyacente de un sustantivo ("Compró papel de envolver"), adyacente de un adjetivo ("Es un problema fácil de resolver") y adyacente de un adverbio: "Nos lo advirtieron antes de empezar". A pesar de ser incompatible con los morfemas verbales, salvo con el de anterioridad ("Mi maestro confesaba haber oído a su abuelo"), puede adoptar términos adyacentes propios del verbo en el grupo unitario, complemento directo ("Prefiero añadir unas palabras"), suplemento ("Tenemos motivos para creer en sus promesas"), complemento indirecto ("Decidió escribir al director"), complemento circunstancial ("Pensó veranear en Málaga"), atributo ("Uno debe ser sincero"), e ir acompañado de un adyacente temático: "El apoyar tú la propuesta me satisface" "74.

${ }^{70}$ E. Alarcos Llorach (1994), p. 143.

${ }^{71}$ E. Alarcos Llorach (1994), p. 143.

${ }^{72}$ E. Alarcos Llorach (1994), p. 143.

${ }^{73}$ E. Alarcos Llorach (1994), p. 143.

${ }^{74}$ Acerca del infinitivo escribió E. Alarcos Llorach en los Estudios de gramática funcional estas reveladoras palabras que reproducimos a continuación: "El infinitivo, o el grupo sintagmático en que aparece, funciona como nombre dentro de la oración. No hay 'oraciones de infinitivo' en el sentido tradicional. Otra cuestión es que el infinitivo, como cualquier otro tipo de sintagma, pueda en ocasiones funcionar aislado como una oración (así en 
El gerundio, "derivado del signo léxico del verbo",75 también, cuyo significante presenta las terminaciones ando (cantando) y iendo (comiendo, viviendo), es susceptible de desempeñar los mismos oficios que el adverbio, por lo que aparece como complemento circunstancial ("Se marchó sonriendo") o como adyacente oracional: "Esforzándose, pudo sacar la carrera". Como el infinitivo, solo conserva el rasgo morfemático verbal de anterioridad ("Entregó el impreso habiéndolo rellenado antes"); como el adverbio, carece de variaciones morfemáticas, siendo susceptible de desarrollar, no obstante, derivados de carácter afectivo ("Se alejó callandito") y posee una amplia libertad de posición en el enunciado. Del mismo modo que el infinitivo, en el grupo nominal unitario puede llevar términos adyacentes, que son "determinaciones o especificaciones de su signo léxico y presentan los rasgos propios de los adyacentes verbales"76, complemento directo ("Preparó el tema leyendo este artículo"), suplemento ("Perdió el tiempo pensando en esas cosas"), complemento directo e indirecto ("Enviando una nota a la empresa, te recibirán"), complemento circunstancial ("Pasa las tardes estudiando en la biblioteca"), atributo ("Siendo prudentes, todo saldrá bien") y, como ocurre con el infinitivo, admitir un adyacente temático: "Asistiendo tú, no habrá discusión". Como el adjetivo, funciona asimismo a veces como adyacente de un sustantivo ("Se cuece con agua hirviendo"), atributo ("Está descansando") o atributo del complemento directo: "Las vi alejándose".

El participio, derivado "de la raíz verbal mediante un derivativo que confiere a la unidad resultante la función propia del adjetivo"77, se caracteriza formalmente por poseer variación de género $(-o /-a)$ y número $(-o s /-a s)$ y admitir gradación mediante los mismos procedimientos que el adjetivo: muy avanzado, más avanzado, tan avanzado, menos avanzado, demasiado avanzado, poco avanzadas, bastante avanzados, avanzadísimo... Como el adjetivo, en el grupo unitario desempeña la función de adyacente nominal del sustantivo ("Comió patatas fritas") y, junto a un verbo copulativo, la de atributo: "El examen ha sido revisado". También como el adjetivo, puede funcionar como complemento predicativo ("Llegaron fatigados a la

¡Callar!, igual que ¡Silencio! o ¡Fuera!). El grupo sintagmático con infinitivo es un sustantivo funcional (y si se quiere ocasional) empleado cuando la sustancia que quiere comunicarse solo puede configurarse en la lengua dada por un conjunto de lexemas; es decir, cuando en la lengua no existe un lexema único que abarque globalmente todos los elementos de sustancia que se pretenden transmitir. // El infinitivo se distingue de los sustantivos normales de la lengua porque los términos adyacentes que pueden acompañarle en grupo sintagmático contraen otro tipo de relaciones, semejantes a las que se establecen con el núcleo verbal de la oración" ([1980], p. 196).

${ }^{75}$ E. Alarcos Llorach (1994), p. 144.

${ }^{76}$ E. Alarcos Llorach (1994), p. 145.

${ }^{77}$ E. Alarcos Llorach (1994), p. 147. 
cumbre") y admitir diversos adyacentes: "Le hicieron un busto esculpido en granito". Por otro lado, con frecuencia forma parte de las llamadas construcciones absolutas, en las que normalmente precede al resto del grupo unitario en el que se halla integrado, que desempeña en su conjunto la función de adyacente oracional: "Terminada la conferencia, el profesor fue muy aplaudido" $"$.

\section{Conclusiones}

L. Penagos, tras haber publicado una gramática latina y otra griega, que tuvieron un éxito editorial destacado, con el precedente de humanistas ilustres como el Catedrático del Instituto San Isidro de Madrid R. de Miguel en el siglo XIX, escribe su Gramática de la lengua española de acuerdo con el modelo seguido en ellas en un momento en el que en los seminarios y centros de Bachillerato el estudio de la lengua española se supeditaba en cierto modo al de la latina y, en su caso, al de la griega, debido a que el latín era la lengua utilizada en la liturgia de la iglesia católica y a que en la sociedad se tenía conciencia de que el conocimiento de nuestra lengua madre y del griego contribuía en gran medida a la formación cultural y lingüística de los estudiantes.

En el contexto en el que es redactada la obra —unos años antes de que penetrasen en nuestro país las nuevas tendencias de la lingüística-, la gramática es presentada el P. Penagos como el conjunto de reglas que enseñan a hablar y escribir correctamente una lengua, y dividida en cuatro partes (morfología, sintaxis, fonética y ortografía), y la oración, definida en un principio desde el punto de vista semántico como la palabra o conjunto de palabras con que expresamos un pensamiento, y posteriormente desde la perspectiva lógico-semántica como la palabra o conjunto de palabras que expresan un juicio, un deseo, un sentimiento, una acción, es clasificada atendiendo a la voz del verbo (activa y pasiva), a la naturaleza del verbo (atributiva y predicativa), al número de verbos (simple y compuesta) y al modo del verbo (independiente y dependiente).

Las oraciones subordinadas, llamadas también dependientes - término predominante en el texto del jesuita del Seminario Menor Pontificio de Comillaspor depender gramaticalmente de otra oración, están distribuidas en tres subgrupos con ulteriores subdivisiones atendiendo al sentido, el de las completivas, que funcionan como complemento o sujeto de la principal; el de las circunstanciales, que expresan alguna circunstancia de la principal; y el de las relativas, que están unidas a la principal por el pronombre relativo. Las completivas se encuentran desglosadas en enunciativas, volitivas e interrogativas; las circunstanciales son estudiadas en dos capítulos diferentes, dedicados, respectivamente, a las de

${ }^{78}$ El participio, inmovilizado en masculino singular, forma parte de las formas compuestas de los verbos: he cantado, habias comido, habrán vivido. 
consecución (finales, consecutivas y causales) y a las de construcción ordinaria (condicionales, concesivas, comparativas, temporales y locativas); y las relativas, según los casos, son interpretadas como adjetivas, circunstanciales o completivas con diversos subtipos establecidos de acuerdo con el sentido.

$\mathrm{Al}$ infinitivo, gerundio y participio L. Penagos les atribuye el carácter de modos impersonales del verbo. En su opinión, el infinitivo desempeña el oficio de una oración o equivale a una oración completiva o circunstancial; el gerundio desempeña el oficio de una oración y equivale a una oración circunstancial o adjetiva; y el participio pasivo, de manera similar al gerundio, también desempeña el oficio de una oración y equivale a una oración circunstancial o adjetiva. En las oraciones de estilo indirecto, en las que se refieren los dichos y pensamientos de otro, no de la misma manera que él las expresó, sino dependiendo de un verbo de decir se destaca el hecho de que se producen cambios en los tiempos y personas verbales, así como en los pronombres y adverbios.

En el contexto actual de la investigación especializada, la gramática, concebida como la parte de la lingüística que estudia la estructura de las palabras, las formas en que estas se enlazan y los significados a los que tales combinaciones dan lugar, suele estudiarse en tres disciplinas, la morfología, que analiza la estructura de las palabras, su constitución interna y sus variaciones, y la sintaxis, que se ocupa de la forma en que se combinan y se disponen linealmente, así como de los grupos que originan, que constituyen la gramática en sentido estricto, a las que se añade la tercera integrada por la fonética y fonología, cuyo cometido son, respectivamente, los sonidos del habla y su organización lingüística en el sistema de la lengua, que se considera parte de la gramática en sentido amplio.

En este marco teórico el enunciado constituye en realidad la unidad lingüística de comunicación, y la oración, el esquema sintagmático verbal u oracional, el tipo esencial de enunciado al que los otros (sustantivo, adjetivo y adverbial), catalizados los elementos del sistema elididos, suelen ser reductibles en última instancia. La oración simple se caracteriza por contener una sola relación predicativa; la compuesta, por constar de varias coordinadas; y la subordinada por el hecho de que en su interior alguna se encuentra transpuesta a la categoría del sustantivo, del adverbio o del adjetivo $\mathrm{y}$, en consecuencia, desempeña una función oracional, en los dos primeros casos, o suboracional, en el tercero, en su estructura.

Las oraciones subordinadas sustantivas (término utilizado después también por L. Penagos en la Lengua española de segundo curso en vez de completivas como reza en la Gramática de la lengua española) han experimentado la sustantivación y desempeñan las funciones categorialmente sustantivas en la estructura oracional; las adjetivas por regla general se obtienen a partir de los relativos con antecedente expreso en transposición simple, pero también se llega a ellas por medio de transposiciones dobles o múltiples; y las adverbiales, conmutables por adverbios, son las de lugar, tiempo y modo sin antecedente expreso, que desempeñan la función de complemento circunstancial. De esta manera, las comparativas y consecutivas se encuentran 
agrupadas con las adjetivas; y las circunstanciales (en ocasiones desglosadas en núcleo y adyacente) suelen constituir segmentos categorialmente sustantivos que funcionan como complemento circunstancial (sobre todo las causales y finales) o adyacente oracional (especialmente las condicionales y concesivas).

El infinitivo, gerundio y participio, las formas no personales del verbo, son unidades derivadas del lexema verbal que desempeñan las funciones propias de los sustantivos, de los adverbios y de los adjetivos, respectivamente. Aunque funcionalmente no son verbos ni constituyen oración, actúan como núcleo dentro del grupo unitario y pueden llevar adyacentes análogos a los que recibe el verbo en la oración. Estas unidades derivadas verbales están constituidas por el signo léxico y un derivativo que les confiere otras posibilidades funcionales y la capacidad de aceptar morfemas de tipo nominal.

Las construcciones en estilo indirecto, en las que se han producido transformaciones con respecto a las correspondientes en estilo directo, desempeñan en la estructura oracional la función de complemento directo, dado que han sido transpuestas a la categoría del sustantivo mediante la conjunción que, con lo que todo el segmento en conjunto es conmutable por la forma pronominal átona neutra lo, por la que también lo es la secuencia en estilo directo, que ha sido transpuesta a la misma categoría por medio de otros procedimientos, desempeñando idéntica función.

En el momento en el que L. Penagos escribe la Gramática de la lengua española, además de resultar impensable que nuestra lengua madre fuera a dejar de ser utilizada en la liturgia de la iglesia católica, tener un sólido conocimiento de las lenguas clásicas era considerado como algo muy importante en la sociedad, y el hecho de usar en ella los mismos conceptos, definiciones y divisiones que en las gramáticas latina y griega con vistas a facilitar el aprendizaje de estas estaba bien visto incluso por el Ministerio de Educación Nacional. Por otro lado, la obra ha quedado como uno de los últimos textos representativos de la gramática tradicional, ya que en la década siguiente comenzarían a aparecer otros basados en las nuevas tendencias de la lingüística, como la Lingüistica española de V. Lamíquiz, de tendencia estructuralista, o la Lengua española de primero de Bachillerato de F. Lázaro y V. Tusón y el Curso de lengua española, de la serie Manuales de Orientación Universitaria, de F. Lázaro, en los que se incorporan los principios de la gramática generativa, de características similares por lo demás en cuanto a su claridad y rigor científico.

\section{Obras citadas}

Alarcos LlORACH, Emilio: Estudios de gramática funcional del español, 3. a ed., Madrid, Gredos, 1980.

Alarcos LloRACH, Emilio: Gramática de la lengua española, Madrid, Real Academia Española, Colección Nebrija y Bello, Espasa Calpe, 1994. 
Alonso, Alonso y Pedro HenRíQuez UreÑA: Gramática castellana, 24. a ed., Buenos Aires, Losada, 1971.

ARNAULD, Antoine y Claude LANCELOT: Grammaire générale et raisonnée, StuttgartBad Cannstatt, Friedrich Fromann Verlag, 1966.

BOSQUE, Ignacio y Violeta DEMONTE (dirs.): Gramática descriptiva de la lengua española. Preámbulo de Fernando Lázaro Carreter, Madrid, Real Academia Española, Colección Nebrija y Bello, Espasa Calpe, 1999.

Condillac, Étienne Bonnot de: Cours d'Étude pour l'instruction du Prince de Parme. I. Grammaire, Londres, Chez les Libraires François, 1776.

GAMBRA GUTIÉRREZ, José Miguel y Manuel ORIOL SALGADO: Lógica aristotélica, Madrid, Dykinson, 2008.

GILI GAYA, Samuel: Curso superior de sintaxis española, 15.. ed., Barcelona, Bibliograf, 2000.

GÓMEZ ASENCIO, José Jesús: Gramática y categorias verbales en la tradición española (1771-1847), Ediciones Universidad de Salamanca, 1981.

HERNANDO CUADRADO, Luis Alberto: "Sobre los estilos del discurso referido", en José Romera Castillo et al. (eds.), Semiótica(s). Homenaje a Greimas, Madrid, Visor, 1994, pp. 251-257.

Jovellanos, Gaspar Melchor de: Curso de humanidades castellanas, Biblioteca de Autores Españoles, XLVI. Obras publicadas e inéditas de D. Gaspar Melchor de Jovellanos. Colección hecha e ilustrada por D. Cándido Nocedal, I, Madrid, Imprenta de Perlado, Páez y Compañía (Sucesores de Hernando), 1903, pp. 101-155.

KeIL, Heinrich (ed.): Grammatici latini, Hildesheim, Georg Olms, 1981.

LALlot, Jean: La Grammaire de Denys le Thrace, Paris, Éditions du Centre National de la Recherche Scientifique, 1989.

LÁZARO, Fernando: Curso de lengua española, Madrid, Anaya, Serie Manuales de Orientación Universitaria, 1978.

LÁZARO, Fernando y Vicente TUSÓN: Lengua española 1 1 , Salamanca, Anaya, 1975.

LAMÍQUIZ, Vidal: Lingüistica española, Universidad de Sevilla, 1973.

LlORENTE MALDONADO DE GUEVARA, Antonio: Teoría de la lengua e historia de la lingüistica, Madrid, Ediciones Alcalá, 1967.

MARÍN Y PEÑA, Manuel: Gramática latina, 5. a ed., Madrid, Sociedad Anónima Española de Traductores y Autores, 1963.

MigUEL, Raimundo de: Gramática hispano-latina teórico-práctica para el estudio simultáneo de las lenguas latina y castellana comparadas, 5. ${ }^{a}$ ed., Madrid, Victoriano Suárez, 1857.

MiguEL, Raimundo de: Gramática castellana comparada a la latina, 2.. ed., Madrid, Sánchez de Jubera Hermanos, Editores, 1865.

PenAGos, Luis: "La doctrina del pecado original en el Concilio de Trento", Miscelánea Comillas. Revista de Teología y Ciencias Humanas, Vol. 3, No 4 (1945), pp. 127-274. 
Penagos, Luis: Gramática griega, 4. a ed., Santander, "Sal Terrae", 1958.

PenAGOS, Luis: Gramática española, Santander, "Sal Terrae", 1959.

PenAGos, Luis: Gramática latina, 12. " ed., Santander, "Sal Terrae", 1960.

PENAGOS, Luis: Gramática de la lengua española, 2. ed., Santander, "Sal Terrae", 1961.

Penagos, Luis: Estilística latina, 3. " ed., Santander, "Sal Terrae", 1962.

PenAGOS, Luis: Gramática de la lengua española, 3. ed., Santander, "Sal Terrae", 1963.

PenAGos, Luis: Oratoria sagrada hoy, Santander, "Sal Terrae", 1964.

PenAgos, Luis: Lengua española. Primer curso, 4. " ed., Santander, "Sal Terrae", 1966.

PenAgos, Luis: Lengua española. Segundo curso, 3. a ed., Santander, "Sal Terrae", 1967.

PENAGOS, Luis (ed.): Florilegio latino. Volumen II, 8. a ed., Santander, "Sal Terrae", 1958.

PenaGos, Luis (ed.): Florilegio latino. Volumen III, 7.a ed., Santander, "Sal Terrae", 1958.

Penagos, Luis (ed.): Florilegio latino. Volumen IV, 4. a ed., Santander, "Sal Terrae", 1964.

PENAGOS, Luis y Mariano RodRÍGUEZ (eds.): Antología griega. Volumen primero, Santander, "Sal Terrae", 1941.

Penagos, Luis y Matías Morán (eds.): Antología griega. Volumen segundo, Santander, "Sal Terrae", 1942.

PenAGOS, Luis y Gregorio RUIZ (eds.): Florilegio latino. Volumen I, 10. ed., Santander, "Sal Terrae", 1957.

RAMUS, Petrus: Grammatica, Londini, Thomas Vautrollerious Typographus, 1585.

ReAl ACADEMIA ESPAÑola: Gramática de la lengua castellana, Madrid, Por D. Joaquín de Ibarra, Impresor de Cámara de S. M, 1771.

REAL ACADEMIA ESPAÑOla: Gramática de la lengua castellana, Madrid, Por la Viuda de Don Joaquín Ibarra, Impresora de la Real Academia, 1796.

REAL ACADEMIA ESPAÑOLA: Gramática de la lengua castellana, Madrid, Imprenta y estereotipia de M. Rivadeneyra, 1870.

REAl ACADEMia EsPaÑola: Gramática de la lengua castellana, Madrid, Perlado, Páez y Compañía (Sucesores de Hernando), Impresores y Libreros de la Real Academia Española, 1916.

ReAl ACADEMia EsPañola: Gramática de la lengua castellana, Madrid, Perlado, Páez y Compañía (Sucesores de Hernando), Impresores y Libreros de la Real Academia Española, 1917.

REAL ACADEMIa ESPAÑola: Gramática de la lengua española, Nueva edición, reformada, de 1931, y apéndice con las Nuevas Normas de Prosodia y Ortografía declaradas de aplicación preceptiva desde $1^{\circ}$ de enero de 1959, Madrid, Espasa Calpe, 1962.

REAL ACADEMIA ESPAÑOlA: Esbozo de una nueva gramática de la lengua española, Madrid, Espasa Calpe, 1973.

Real ACADEMIA ESPañola: Diccionario de la lengua española, 21. ${ }^{a}$ ed., Madrid, Espasa Calpe, 2001. 
REAL ACADEMIA ESPaÑola y Asociación DE ACADEMIAS DE LA LENGUA ESPAÑOLA: Nueva gramática de la lengua española, Madrid, Espasa Libros, 2009.

ROCA PONS, José: Introducción a la gramática (con especial referencia a la lengua española), 7. . ed., Barcelona, Teide, 1986.

SÁNCHEZ DE LAS BROZAS, Francisco: Minerva o De causis linguae latinae. Introducción y edición de Eustaquio Sánchez Salor (Libri I, III y IV); edición de César Chaparro Gómez (Liber II), Cáceres, Institución Cultural "El Brocense", Excma. Diputación Provincial de Cáceres y Universidad de Extremadura, 1995.

SAPIR, Edward: Language. An introduction to the study of speech, San Diego, Harcourt Brace Jovanovich, 1992.

VILla DEI, Alexander de: Doctrinale pro eruditione puerorum. Cum commento Ludovici de Guaschis, Barcelona, Petrus Rosa, 1493. 